\title{
EFEKTIFITAS ANTIBAKTERI EKSTRAK BUAH NAGA SUPER MERAH (Hylocereus costaricensis) TERHADAP PERTUMBUHAN BAKTERI Streptococcus mutans
}

\section{EFFECTIVENESS OF ANTIBACTERIAL EXTRACT OF SUPER RED DRAGON FRUIT (Hylocereus costaricensis) ON THE GROWTH OF BACTERIA Streptococcus mutans}

\author{
Bambang Tri Hartomo ${ }^{1 *}$, Fanny Kusuma Djati ${ }^{1}$, Fitri Diah Oktadewi ${ }^{1}$, Angger Waspodo \\ Dias Adrianto ${ }^{2}$,Prasetyo Adi Nugroho ${ }^{1}$ \\ ${ }^{1}$ Jurusan Kedokteran Gigi Fakultas Kedokteran Unsoed \\ Kampus Unsoed Karangwangkal Gedung E Jl.Suparno Purwokerto \\ ${ }^{2}$ Fakultas Kedokteran Gigi Universitas Muhammadiyah Semarang \\ Kedung Mundu Raya no.22 Sendangmulyo Tembalang, Kota Semarang
}

\begin{abstract}
ABSTRAK
Buah naga super merah (Hylocereus costaricencis) saat ini dibudidayakan oleh Kebun Benih Holtikultura Baturaden sebagai produk unggulan yang berpotensi meningkatkan kesejahteraan masyarakat Banyumas. Buah naga super merah diyakini memiliki efek anti bakteri oleh karena kandungan polifenol yang terdapat pada daging buah maupun kulit buah naga. Penelitian ini bertujuan untuk melihat daya hambat ekstrak buah naga super merah terhadap pertumbuhan bakteri Streptococcus mutans yang merupakan salah satu pencetus terjadinya penyakit periodontal. Sebagai langkah awal, dilakukan uji determinasi buah naga super merah untuk memastikan bahwa buah naga yang digunakan adalah buah naga super merah. Selanjutnya dilakukan pembuatan ekstrak dengan metode maserasi. Hasil penelitian antar perlakuan menunjukan bahwa tidak terdapat perbedaan daya hambat bakteri yang signifikan $(p>0,05)$ antara ekstrak buah naga super merah, kontrol positif dan kontrol negatif. Penelitian ini menyimpulkan bahwa ekstrak buah naga super merah dapat digunakan sebagai bahan antibakteri dalam terapi periodontal. Hasil penelitian ini diharapkan akan menjadi acuan untuk langkah berikutnya yaitu pengujian efek anti bakteri larutan buah naga super merah terhadap akumulasi plak pada rongga mulut.
\end{abstract}

Kata kunci: buah naga, Hylocereus costranicencis , penyakit periodontal, plak, Streptococcus mutans 


\begin{abstract}
Super red dragon fruit (Hylocereus costaricencis) is currently cultivated by the Baturraden Horticultural Seed Garden as a superior product that has the potential to improve the welfare of the Banyumas community. Dragon fruit is believed to have anti-bacterial effects because of the polyphenol content found in fruit flesh and dragon fruit skin. This study aims to see the inhibitory power of super red dragon fruit extract on the growth of Streptococcus mutans bacteria which is one of the triggers of periodontal disease. As a first step, a determination of dragon fruit is determined to ensure that the dragon fruit used is super red dragon fruit. Furthermore, the extract was made by maceration method. The results of the study between treatments showed that there was no significant difference in bacterial inhibition $(\mathrm{p}>0.05)$ between super red dragon fruit extract, positive control and negative control. This study concluded that super red dragon fruit extract can be used as anti bacterial agent for periodontal therapy. The results of this study are expected to be a reference for the next research, analyzing the antibacterial effect of super red dragon fruit solution to the accumulation of plaque on the oral cavity.

Keywords: dragon fruit, Hylocereus costranicencis, periodontal disease, plaque, Streptococcus mutans,
\end{abstract}

\title{
Penulis korespondensi:
}

Bambang Tri Hartomo,

Jurusan Kedokteran Gigi Fakultas Kedokteran Universitas Jenderal Soedirman

Kampus Unsoed Karangwangkal Gedung E Jalan DR.Suparno.

Email: bambang.tri..hartomo@gmail.com / bambang.hartomo@unsoed.ac.id

\section{PENDAHULUAN}

Akumulasi plak pada gigi yang sejatinya merupakan proses alamiah dalam diri seseorang dapat menimbulkan masalah pada rongga mulut jika tidak dikontrol dengan baik. Plak (plaque) adalah lapisan tipis, biofilm dari kumpulan bakteri yang ada dalam rongga mulut. Plak melekat erat pada setiap permukaan keras yang ada dalam rongga mulut seperti gigi, restorasi permanen, maupun perangkat geligi tiruan. Ketidakseimbangan akumulasi plak dalam rongga mulut menjadi salah satu pemicu timbulnya gingivitis maupun periodontitis. Setiap $1 \mathrm{~mm}^{3}$ plak (setara dengan 1 mg plak), dijumpai $10^{3}$ koloni bermacam bakteri rongga mulut (Lindhe, 2015). Plak menjadi etiologi terjadinya inflamasi pada gingiva jika mekanisme pertahanan tubuh seseorang pada rongga mulut tidak berjalan dengan baik. Kondisi oral hygiene yang buruk karena perilaku kesehatan gigi yang tidak baik ditambah faktor lokal berupa tumpukan kalkulus dan stain, susunan gigi geligi yang bertumpuk, serta restorasi yang overhanging meningkatkan kuantitas plak. Kondisi sistemik yang tidak baik akan berdampak pada turunnya mekanisme pertahanan tubuh sehingga plak semakin resisten (Carranza,2012).

Pengendalian plak secara simultan yang dilakukan baik secara mekanis maupun kimiawi merupakan kunci untuk mencapai kondisi yang ideal pada rongga mulut. Pengendalian secara mekanis dapat dilakukan dengan menggunakan sikat gigi, sikat interdental, dan benang gigi. Pengendalian secara kimiawi dapat dilakukan dengan 
pemberian obat kumur berbahan antiseptik dan antibakteri kimia buatan berbasis chlorhexidine, listerine, maupun triklosan dan amoksisilin. Selain itu, penggunaan bahan kimia alami seperti propolis sebagai media kumur diketahui efektif untuk mengendalikan plak pada rongga mulut (Thosar, dkk., 2016). Penggunaan bahan kimia buatan dalam jangka panjang seperti chlorhexidine dapat mengakibatkan munculnya pewarnaan pada gigi, restorasi, maupun perangkat geligi tiruan. Area dorsal lidah yang merupakan jaringan lunak juga terpengaruh akibat penggunaan jangka panjang dari chlorhexidine. Sebaliknya, penggunaan bahan kimia alami sebagai agen pengendali plak memiliki efek yang lebih aman (Balagopal, 2013).

Buah Naga Super Merah (Hylocereus costaricencis) memiliki sifat antioksidan karena mengandung vitamin $\mathrm{A}$, vitamin $\mathrm{C}$, vitamin $\mathrm{E}$, polifenol, likopen dan betasianin (Omidizadeh, dkk., 2014). Polifenol yang terdapat buah Naga Super Merah memiliki sifat antibakteri, salah satunya terhadap bakteri Streptococcus mutans karena dapat menghilangkan makromolekul dalam sel akibat adanya perubahan permeabilitas didalam sel (Peschel, 2013). Kabupaten Banyumas dengan kondisi alamnya yang ideal melalui Kebun Benih Holtikultura Baturaden saat ini telah berhasil mengembangkan buah Naga Super Merah (Hylocereus costaricencis). Kondisi ini sejalan dengan kebijakan Pemerintah Republik Indonesia di bidang kesehatan yang mendukung upaya masyarakat untuk mengembangkan obat alami selama tidak bertentangan dengan norma dan budaya yang berlaku di Indonesia (BP2TPH,2016). Pengembangan obat-obatan tradisional berbasis kimia alami berpotensi meningkatkan kesejahteraan masyarakat Indonesia di bidang kesehatan, ekonomi, ketahanan sehingga mampu bersaing di era perdagangan bebas. Besarnya potensi buah Naga Super Merah (Hylocereus costaricencis) ini menjadi pijakan penting untuk dilakukannya penelitian lebih jauh tentang pengaruh larutan buah naga super merah (Hylocereus costaricencis) terhadap akumulasi plak pada gigi, sesuai dengan visi Unsoed 2020 yaitu menjadi Universitas bertaraf Internasional yang memasyarakat dan memilki keunggulan ilmu pengetahuan, teknologi, dan atau seni yang relevan dengan pengembangan sumber daya perdesaan dan kearifan lokal yang berkelanjutan.

\section{METODE PENELITIAN}

Jenis penelitian yang digunakan adalah experimental laboratorium dengan rancangan posttest only control group design. Penelitian yang dilakukan yaitu mengukur pengaruh perlakuan pada kelompok eksperimen dengan cara membandingkan kelompok tersebut dengan kelompok kontrol (Notoatmodjo, 2010). Penelitian ini dilakukan pada tiga kelompok perlakuan, yaitu koloni bakteri yang diberi ekstrak buah Naga Super Merah (Hylocereus costaricencis) dibandingkan dengan kelompok kontrol yaitu koloni bakteri yang diberi akuades dan amoksilin. Hasil uji daya hambat diamati setelah masa inkubasi 1x 24 jam dan 2x 24 jam. Variabel bebas dalam penelitian ini adalah ekstrak buah naga super merah (Hylocereus costaricencis). Variabel terikat pada penelitian ini adalah daya hambat Streptococcus mutant.Variabel terkendali dalam penelitian ini adalah berat buah naga serta frekuensi pemberian ekstrak buah naga.

\section{Alat dan Bahan}

Alat yang digunakan dalam penelitian ini meliputi gelas kimia, timbangan digital, pisau stainless stell, tampah, evaporator, kertas alumunium, pipet tetes, cawan petri, pengaduk, mangkuk, deligen kosong, spatula, botol vial berukuran 10ml, thermolyne, pipet tetes, corong, tabung erlenmeyer. Bahan yang digunakan dalam penelitian ini adalah daging buah Naga Super Merah (Hylocereus costranicensis), larutan etanol 70\%, larutan akuades, gliserin propilenglikol, Na-sakarin dan mentol. 


\section{Jalannya Penelitian}

\section{a. Determinasi tanaman buah Naga Super Merah (Hylocereus costranicensis)}

Buah Naga Super Merah didapatkan dari Balai Benih Tanaman Pangan dan Hortikultura wilayah Banyumas, Baturaden. Determinasi dilakukan untuk memastikan bahwa buah yang digunakan di dalam penelitian ini adalah buah Naga Super Merah (Hylocereus costranicensis). Determinasi tanaman dilakukan di Laboratorium Taksonomi Tumbuhan Fakultas Biologi Universitas Jenderal Soedirman.

\section{b. Pembuatan ekstrak buah Naga Super Merah (Hylocereus costranicensis)}

Pembuatan ekstrak buah Naga Super Merah dilakukan menurut metode Umayah dan Amrun (2007) di Laboratorium Ekotoksikologi Fakultas Biologi Universitas Jenderal Soedirman dengan metode maserasi. Langkah pertama dengan memotong buah Naga Super Merah sehingga berukuran 1x1x1 cm, lalu dilakukan penjemuran di bawah sinar matahari selama 3 hari sampai kadar airnya berkurang. Setelah 3 hari buah naga ditimbang hingga mencapai 10 gram, kemudian dimasukkan kedalam gelas ukur untuk kemudian ditambahkan etanol sebanyak $150 \mathrm{ml}$. Langkah berikutnya adalah menutup rapat gelas ukur yang sudah berisi campuran buah naga dan etanol dengan aluminium foil dan mendiamkannya selama 1x24 jam. Larutan etanol diganti tiap 24 jam sampai 3 hari berturut-turut dan hasil pengumpulannya dimasukkan ke dalam jerigen kecil yang tertutup rapat. Hasil pengumpulan larutan etanol kemudian dievaporasi selama 90 menit kemudian dilakuan pengenceran ekstrak buah naga super merah. Pengenceran dilakukan dengan menggunakan akuades steril untuk mendapatkan konsentrasi $75 \%$ dan 50\% dari ekstrak buah naga super merah konsentrasi $100 \%$.

Uji Wilstatter, uji Bate-Smith, dan uji dengan $\mathrm{NaOH} 10 \%$ digunakan untuk uji keberadaan senyawa flavonoid dari dalam sampel, sedangkan uji adanya senyawa polifenol dilakukan dengan larutan penambahan $\mathrm{FeCl} 3$.

\section{c. Uji ekstrak etanol buah Naga Super Merah terhadap bakteri Streptococcus mutans}

Uji ekstrak etanol buah naga super merah dilakukan dengan metode Kirby-Bauer atau metode difusi cakram. Pada metode difusi cakram digunakan cakram kertas saring yang mengandung larutan ekstrak buah naga super merah dengan konsentrasi tertentu yang ditempelkan pada lempeng agar yang telah ditanami bakteri Sterptococcus mutans. Hambatan (Inhibition zone) akan tampak sebagai daerah yang tidak memperlihatkan pertumbuhan kuman disekitar cakram. Lebar daerah hambatan tergantung ada atau tidaknya daya serap ektrak kedalam agar dan kepekaan bakteri Streptococcus mutans terhadap ekstrak buah naga super merah sebagai perlakuan dan akuades serta amoksilin sebagai kontrol. Metode ini dilakukan selama 2 hari dengan cara melakukan pengamatan dan pengukuran zona hambat yang terbentuk pada hari pertama dan hari kedua.

\section{Analisis Data}

Data dianalisis dan diolah menggunakan SPSS. Analisis yang dilakukan meliputi analisis deskriptif sebagai salah satu jenis analisis dengan memberikan gambaran (deskripsi) mengenai suatu data yang diperoleh. Uji Normalitas dilakukan dengan tahap uji Shapiro-Wilk untuk melihat distribusi data dilanjutkan dengan uji homogenitas dengan menggunakan uji Lavene"s Test. Langkah berikutnya adalah melakukan uji efek perlakuan pada data yang berdistribusi normal dan homogen, dengan menggunakan uji statistik parametrik Paired sample T-Test untuk analisis perbandingan pre test dan post test pada masing-masing kelompok dan Independent sample T-Test untuk analisis perbandingan kelompok perlakuan dan kelompok kontrol. 


\section{HASIL DAN PEMBAHASAN}

Determinasi buah Naga Super Merah (Hylocereus costaricensis) dilakukan di Laboratorium Taksonomi Tumbuhan Fakultas Biologi Universitas Jenderal Soedirman dengan hasil sebagai berikut (Tabel I).

Tabel I. Hasil pengujian determinasi buah naga super merah (hylocereus costaricensis)

\begin{tabular}{ll}
\hline \multicolumn{1}{c}{ Deteriminasi } & \multicolumn{1}{c}{ Keterangan } \\
\hline Familia & Cactaceae \\
Species & Hylocereus costaricensis \\
Nama local & Buah Naga Super Merah \\
Referensi & The Plant List (2013). Version 1.1. published on \\
& internet; http://www.theplantlist.org/ \\
Determiner & SK \\
\hline
\end{tabular}

Hasil determinasi sampel buah Naga Super Merah pada tabel I diatas secara berturut-turut adalah familia Cactaceae, speciesnya adalah Hylocereus costraricensis dan nama lokalnya adalah Buah Naga Super Merah. Hal ini sesuai dengan ciri-ciri yang dimiliki Tanaman buah Naga Super Merah yaitu merupakan tanaman merambat. Pada lingkungan alaminya buah Naga Super Merah dapat ditemui pada batang tanaman lain yang lebih kuat. Tanaman ini dikembangbiakan sebagai tanaman epifit dengan sumber makanan diperoleh dari akar udara yang terdapat pada batangnya, hanya memiliki akar, batang, bunga, buah dan biji, tanpa daun (Kristanto,2009).

Langkah selanjutnya yaitu pengekstraksian buah Naga Super Merah di Laboratorium Ekotoksikologi Fakultas Biologi Universitas Jenderal Soedirman dengan teknik maserasi dengan pelarut etanol $70 \%$. Pelarut etanol digunakan karena merupakan zat pelarut yang dapat mengikat senyawa-senyawa yang terkandung dalam buah Naga Super Merah seperti flavonoid. Flavonoid berguna untuk menghambat pertumbuhan bakteri. Ekstraksi ini menggunakan metode maserasi dikarenakan tidak memakan biaya yang banyak dan proses nya mudah.

Setelah dikumpulkan selama 5 hari, dilakukan evaporasi selama 90 menit untuk melepaskan pelarut/ etanol sehingga yang tersisa adalah ektrak dari buah Naga Super Merah itu sendiri. Proses ekstraksi yang dilakukan terhadap buah Naga Super Merah diperoleh ekstrak kental sebanyak 9,53 g. Karakter ekstrak secara organoleptis adalah berupa ekstrak cairan kental, berwarna merah pekat dan berbau khas. Ekstrak mudah larut dalam air dan etanol. Pada uji skrining fitokimia, ekstrak mengandung metabolit sekunder golongan fenol yaitu flavonoid. Flavonoid merupakan senyawa pereduksi yang baik dan dapat menghambat banyak reaksi oksidasi, baik secara enzim maupun nonenzim. Flavonoid melindungi membran lipid terhadap reaksi radikal hidroksi dan superoksida yang merusak.

Hasil uji Bate-Smith menggunakan $\mathrm{HCl}$ yang dipanaskan dengan waktu 15 menit di atas penangas air menunjukan bahwa ekstrak etanol buah naga super merah (Hylocereus costaricensis) mengandung senyawa flavonoid dibuktikan dengan adanya reaksi positif berupa warna merah pekat dari hasil pemanasan. Uji Bate-Smith ekstrak buah Naga Super Merah menunjukkan bahwa buah Naga Super Merah dapat berfungsi sebagai anti bakteri.

Tahap selanjutnya yaitu uji daya hambat ekstrak buah Naga Super Merah terhadap Streptococcus mutans. Ekstrak buah Naga Super Merah sebagai perlakuan, amoksisilin sebagai 
kontrol positif, dan akuades sebagai kontrol negatif. Hasil uji daya hambat ekstrak buah Naga Super Merah terhadap bakteri Streptococcus mutans disajikan pada gambar 1

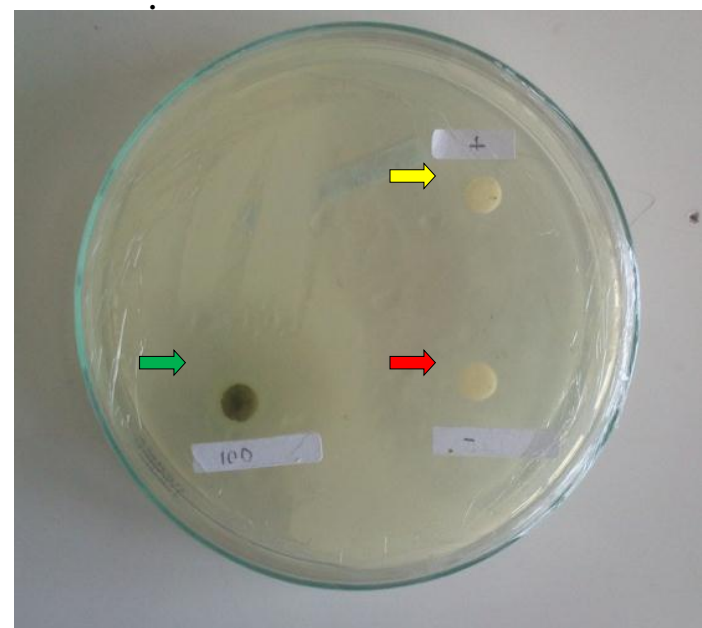

a

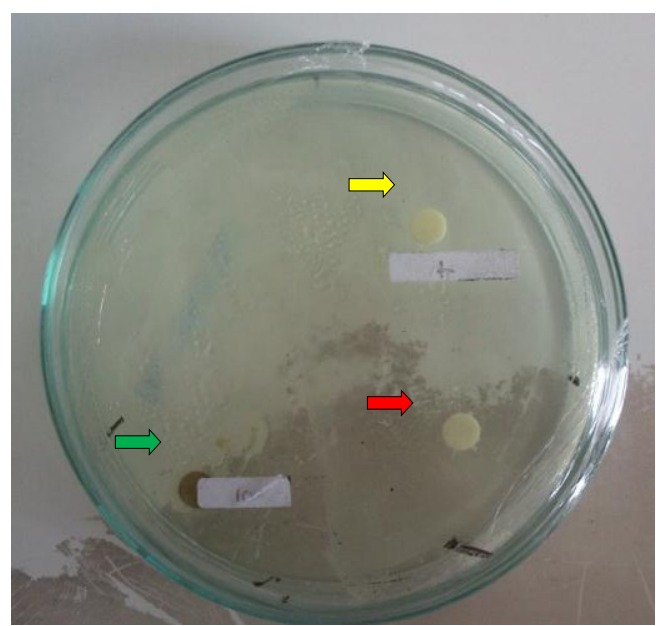

b

Gambar 1 Hasil uji antibakteri Streptococcus mutans dengan masa inkubasi 1 hari (a), 2 hari (b)

Keterangan :

$\Rightarrow \quad$ : kontrol negatif (akuades)

$\Rightarrow \quad$ : kontrol positif (amoksisilin)

$\Rightarrow \quad$ : ekstrak buah naga super merah

Setelah dilakukan uji daya hambat, selanjutnya dilakukan pengukuran zona hambat atau zona bening yang terbentuk di sekitar bahan uji. Hasil pengukuran dengan menggunakan jangka sorong dapat dilihat pada tabel II.

Tabel II. Hasil perhitungan zona hambat yang terbentuk disekitar bahan uji menggunakan jangka sorong

\begin{tabular}{|c|c|c|c|c|c|c|}
\hline \multicolumn{7}{|c|}{ Diameter zona hambat (mm) } \\
\hline \multirow{2}{*}{$\begin{array}{l}\text { Perlakuan } \\
\text { Waktu }\end{array}$} & \multicolumn{2}{|c|}{ buah naga super merah } & \multicolumn{2}{|c|}{ Amoksisilin } & \multicolumn{2}{|c|}{ Akuades } \\
\hline & $1 \times 24$ jam & $2 \times 24$ jam & $1 \times 24$ jam & $2 \times 24$ jam & $1 \times 24$ jam & $2 \times 24$ jam \\
\hline 1 & 27,8 & 27,4 & 42,7 & 39,4 & 6,2 & 5,9 \\
\hline 2 & 28,2 & 31 & 39,9 & 45 & 6,23 & 6,2 \\
\hline
\end{tabular}

Tabel II menunjukkan bahwa ekstrak buah Naga Super Merah, amoksisilin dan akuades memiliki daya hambat terhadap bakteri Streptococcus mutans. Pada tabel II juga menunjukkan adanya perubahan zona hambat ekstrak buah naga super merah, amoksisilin, dan akuades pada inkubasi 1x24 jam dan 2x24 jam. Daya hambat keduanya meningkat seiring dengan bertambahnya waktu inkubasi atau daya hambat berbanding lurus dengan waktu. Pada kelompok ekstrak buah Naga Super Merah dengan masa inkubasi 1x24 jam memiliki zona hambat terkecil 27,8 mm dan terbesar 28,2 mm. Pada ekstrak buah Naga Super Merah dengan masa inkubasi 2x24 jam memiliki zona hambat terkecil 27,4 $\mathrm{mm}$ dan terbesar $31 \mathrm{~mm}$. Pada kelompok amoksisilin dengan masa 
inkubasi 1x24 jam memiliki zona hambat terkecil 39,9 $\mathrm{mm}$ dan terbesar 42,7 mm. Sedangkan pada amoksisilin dengan masa inkubasi 2x24 jam memiliki zona hambat terkecil 39,4 mm dan terbesar $45 \mathrm{~mm}$. Pada kelompok akuades dengan masa inkubasi 1x24 jam memiliki zona hambat terkecil $6,2 \mathrm{~mm}$ dan terbesar $6,23 \mathrm{~mm}$. Sedangkan pada akuades dengan masa inkubasi $2 \times 24$ jam memiliki zona hambat terkecil $5,9 \mathrm{~mm}$ dan terbesar $6,2 \mathrm{~mm}$. hasil uji daya hambat menunjukan bahwa ekstrak buah naga efektif untuk menghambat pertumbuhan dan perkembangbiakan dari bakteri Streptococcus mutan.

Pada hasil uji statistik, uji homogenitas dengan Levene test didapatkan nilai signifikansi kurang dari 0,05 ( $\mathrm{p}<0,05)$. Karena data tidak terdistribusi normal maka dilakukan uji KruskalWallis untuk mengetahui perbandingan efektifitas daya hambat bakteri ekstrak buah naga super merah dengan kelompok kontrol positif dan kontrol negatif, lalu dilakukan uji dengan independent t test untuk mengetahui perbandingan efektifitas daya hambat bakteri buah naga super merah pada waktu inkubasi $1 \times 24$ jam dengan 2x24 jam.

a. Hasil perbandingan kelompok

Perbedaan daya hambat antibakteri ekstrak buah Naga Super Merah dengan kelompok kontrol positif dan negatif dilakukan dengan uji Kruskal-Wallis. Hasil uji Kruskal-Wallis dapat dilihat pada Tabel III.

Tabel III. Hasil Uji Kruskal-Wallis Antar perlakuan ekstrak buah Naga Super Merah, amoksisilin, dan akuades

\begin{tabular}{ccc}
\hline No. & & Daya hambat \\
\hline 1. & Chi-Square & 10,054 \\
2. & Df & 5 \\
3. & Asymp. Sig. & 0,074 \\
\hline
\end{tabular}

Hasil uji Kruskal-Wallis antar perlakuan diperoleh nilai p sebesar 0,074 (p>0,05) sehingga dapat diambil kesimpulan tidak terdapat perbedaan yang signifikan daya hambat bakteri antar ekstrak buah naga super merah, amoksisilin, dan akuades.

b. Hasil kelompok waktu

Perbedaan daya hambat ekstrak buah naga super merah terhadap bakteri Streptococcus mutans pada kelompok waktu 1x24 jam dan 2x24 jam dilakukan uji Independent t test. Hasil uji Independent t test dapat dilihat pada Tabel 4.

Tabel 4. Hasil Uji Independent t test Antar Waktu Inkubasi Daya Hambat Ekstrak Buah Naga Super Merah Terhadap Bakteri Streptococcus mutans

\begin{tabular}{ccccc}
\hline Kelompok & $\mathbf{N}$ & Mean & Standar Deviasi & Sig (2 tailed) \\
\hline 1x24 jam & 2 & 28 & 0,28284 & \\
2x24 jam & 2 & 29,2 & 2,54558 & 0,576 \\
\hline
\end{tabular}

Hasil uji Independet t test antar waktu inkubasi diperoleh nilai p sebesar 0,576 ( $p>0,05)$, sehingga dapat diambil kesimpulan tidak terdapat perbedaan yang signifikan antar waktu $1 \times 24$ jam dan 2x24 jam daya hambat ekstrak buah Naga Super Merah terhadap bakteri 
Streptococcus mutans. Uji independent t-test antar waktu inkubasi menunjukkan ekstrak buah Naga Super Merah layak dalam menghambat pertumbuhan bakteri Streptococcus mutans.

Hasil penelitian ini berbeda dengan penelitian Mujiatmaja (2016) dan Anggraini et al. (2017). Mujiatmaja menyatakan bahwa pemberian buah Naga Merah konsentrasi 3\%, 5\%, dan 9\% dengan masa inkubasi 1 x 24 jam dapat meningkatkan daya hambat pertumbuhan bakteri Fusobacterium nucleatum (Mujiatmaja, 2016). Sedangkan penelitian Anggraini et al. (2017) menyatakan bahwa ekstrak kulit buah Naga Putih (Hylocereus undatus) mampu menghambat bakteri Staphylococcus epidermis dengan diameter rata-rata zona hambat dengan kosentrasi $25 \%$ yaitu $13,7 \mathrm{~mm}, 50 \%$ yaitu $15,2 \mathrm{~mm}, 75 \%$ yaitu $16,3 \mathrm{~mm}$ dan $100 \%$ yaitu $17,7 \mathrm{~mm}$. Dari rata-rata zona hambat yang terbentuk ekstrak kulit Buah Naga Putih (Hylocereus undatus) memiliki kekuatan daya hambat terhadap bakteri Staphylococcus epidermidis dalam kategori kuat.

Flavonoid merupakan golongan terbesar dari senyawa fenol dan memiliki mekanisme kerja dalam menghambat pertumbuhan bakteri dengan cara menginaktivasi protein enzim pada membran sel, sehingga mengakibatkan struktur protein menjadi rusak. Ketidakstabilan pada dinding sel dan membran sitoplasma bakteri akan mengakibatkan fungsi permeabilitas selektif, fungsi pengangkutan aktif, pengendalian susunan protein dari sel bakteri menjadi terganggu, sehingga akan menyebabkan hilangnya makromolekul dan ion dari sel, sehingga sel bakteri menjadi kehilangan bentuk dan selanjutnya akan terjadi lisis (Mujiatmaja, 2016).

Bakteri Streptococcus mutans merupakan salah satu penyebab penyakit periodontal seperti gingivitis dan periodontitis. Bakteri lain yang dapat berperan adalah Porphyromonas gingivalis, Prevotella intermedia, Bacteriodes forsythus, Fusobacterium nucleatum, Campylobacter dan Selemonas (Chetrus, 2013). Penggunaan ekstrak buah Naga Super Merah sebagai agen antibakteri perlu dilakukan penelitian mendalam mengingat buah naga sangat berpotensi untuk dikembangkan sebagai produk unggulan di wilayah kabupaten Banyumas. Pada penelitian ini, tidak ditemukan adanya perbedaan yang signifikan antara daya hambat anti bakteri ekstrak buah Naga Super Merah dengan dengan kontrol. Hal ini kemungkinan dikarenakan sedikitnya jumlah pengamatan untuk masa inkubasi, atau tidak berkelanjutan untuk pengamatan 3x24 jam dan seterusnya sehingga pada saat pengolahan data, uji t tidak menunjukkan pengaruh waktu yang bermakna.

Perlu diadakan penelitian selanjutnya dengan mengamati zona hambat yang terbentuk pada masa inkubasi yang lebih dari $2 \times 24$ jam untuk mengetahui secara pasti pengaruh waktu terhadap daya hambat ekstrak buah Naga Super Merah.

Keterbatasan penelitian ini adalah tidak menampilkan variabel konsentrasi buah Naga Super Merah yang mempengaruhi perbedaan daya hambat terhadap pertumbuhan Streptococcus mutans.

\section{KESIMPULAN}

Tidak terdapat perbedaan yang bermakna antara masa inkubasi 24 jam dengan 48 jam pada uji daya hambat ekstrak buah Naga Super Merah terhadap bakteri Streptococcus mutans. 


\section{UCAPAN TERIMAKASIH}

Terimakasih penulis ucapkan kepada Balai Benih Tanaman Pangan dan Hortikultura wilayah Banyumas, Baturaden, Dekan Fakultas Kedokteran Universitas Jenderal Soedirman, Ketua Jurusan Kedokteran Gigi, Rekan Peneliti dan laboran di Laboratorium Taksonomi Tumbuhan Fakultas Biologi dan Laboratorium Mikrobiologi Fakultas Kedokteran Universitas Jenderal Soedirman serta LPPM Universitas Jenderal Soedirman yang telah membantu proses pendanaan penelitian dengan skema riset dosen pemula.

\section{DAFTAR PUSTAKA}

Anggraini, H., Fakhrurrazi, Harris, A. 2017. Uji antibakterial ekstrak kulit buah naga putih (Hylocereus undatus) terhadap bakteri Staphylococcus epidermidis. JIMVET 1 (3): 416423.

Balagopal, S. 2013. The gold standard antiplaque agent. J.of Pharmaceutical and Research 5(12): 270-274.

BP2TPH Banyumas. 2016. Rahasia Melimpah Panen Buah Naga di TBH Baturraden. Dinas Pertanian dan Tanaman Pangan Jawa Tengah.

Carranza, F.A., and Shklar, G. 2012. The historical background of periodontology. In Newman, Takei, Klokkevold. (Editors). Carranza's Clinical Periodontology. 11th ed. St.Louis. Elsevier Saunders.

Chetrus, V. 2013. Dental plaque- classification,formation, and identification. Int. J.of Medical Dentistry 3(2): 139-143.

Kristianto, D. 2009. Buah Naga: Pembudidayaan Di Pot Dan Kebun. Jakarta. Penebar Swadaya.

Lidhe, J. 2015. Clinical Periodontology And Implant Dentistry $6^{\text {th }}$. Blackwell Muksgaard. Oxford. Mahmudah, F.L. 2017. Antibacterial activity test of ethanol extract temu kunci (Boesenbergia pandurata) against Streptococcus mutans bacteria. Jurnal Penelitian Saintek 22(1):59-66.

Mujiatmaja, N.K.H. 2016. Pengaruh Penambahan Berbagai Konsenstrasi Ekstrak Kulit Buah Naga Merah Pada Antibiotik Terhadap Peningkatan Hambatan Pertumbuhan Bakteri Fusobacterium nucleatum Dominan Periodontitis in vitro. Thesis. Universitas Muhammadiyah Surakarta.

Notoatmodjo, S. 2010. Metodologi Penelitian Kesehatan. Jakarta. Rineka Cipta.

Omidizadeh. 2011. Cardioprotective compounds of red pitaya (Hylocreus polyrhizus) fruit. J.of Food,/Agriculture \&Environment 9 (3\&4): 152-156.

Umayah, E., dan Amrun, H. 2007. Antioxidant activity assay of dragon fruit extract. Jurnal Ilmu Dasar 8(1): 83-90. 
Peschel, A. 2013. Phenol-soluble modulins and stafilococcal infection. Nature Reviews Microbiogy 11: 667-673.

Thosar, N. 2016. Changing trends in oral hygiene and plaque control in chidren. J.of Oral Dentistry and oral Care 2(1):1-5. 